\title{
Effect of deep litter housing and fermented feed on carcass characteristics and meat quality of crossbred Hampshire pigs
}

\author{
M. Rahman, J. R. Bora, A. K. Sarma, R. Roychoudhury and A. Borgohain \\ Department of Livestock Production and Management, College of Veterinary Science, Assam Agricultural University, \\ Khanapara, Guwahati-781 022, Assam, India. \\ Corresponding author: M. Rahman, e-mail: mstfzr.rhmn@gmail.com, JRB: jrbora_1962@yahoo.co.in, \\ AKS: arupsarma.1241@rediffmail.com, RR: bapubosconian@gmail.com, AB: atulborg@yahoo.com \\ Received: 04-02-2014, Revised: 08-06-2015, Accepted: 16-06-2015, Published online: 16-07-2015
}

doi: 10.14202/vetworld.2015.881-887 How to cite this article: Rahman M, Bora JR, Sarma AK, Roychoudhury R, Borgohain A (2015) Effect of deep litter housing and fermented feed on carcass characteristics and meat quality of crossbred Hampshire pigs, Veterinary World 8(7): 881-887.

\begin{abstract}
Aim: The objective of the study was to evaluate the effect of deep litter housing and fermented feed on carcass characteristics and meat quality of crossbred Hampshire pigs.

Materials and Methods: Forty-eight weaned crossbred Hampshire piglets of 2 months age (24 males and 24 females) were selected for the experiment. The piglets were randomly assigned into 4 homogenous experimental groups with 6 males and 6 females each: $\mathrm{E}_{1}$; reared on a conventional housing and fed with a fermented diet, $\mathrm{E}_{2}$; reared on a deep litter housing system and fed with a fermented diet, $\mathrm{E}_{3}$; reared on a deep litter housing system and fed with a conventional diet and $\mathrm{C}$; reared on a conventional housing system and fed with a conventional diet. The study was continued up to 32 weeks of age and at the end of this period, 6 animals ( 3 males and 3 females) from each experimental group were slaughtered to evaluate carcass traits and meat quality characteristics.
\end{abstract}

Results: Pre-slaughter weight, hot carcass weight, and dressing percentage were significantly $(p<0.01)$ affected by feeding fermented diet and deep litter housing while carcass traits, i.e., carcass length, backfat thickness, and loin eye area were not affected. The edible offal; liver and heart weight $(\mathrm{p}<0.05)$ differed significantly while kidney weight showed no difference. The inedible offal; head weight $(\mathrm{p}<0.01)$ and lung weight revealed a significant difference $(\mathrm{p}<0.05)$ while spleen and stomach weight showed no difference among the experimental groups. The wholesale cuts and meat: bone ratio of pigs also differed significantly among the groups. Morphometry of small and large intestine also showed a significant difference. Chemical composition of pork viz., moisture and total ash content was influenced by the treatment, while crude protein and ether extract content were not affected. Mineral composition of pork also showed no significant difference. Color characteristics of Longissimus dorsi muscle showed a significant difference in $\mathrm{L}^{*}$ and $\mathrm{a}^{*}$ value while parameter $\mathrm{b}^{*}$ was not affected. The tenderness of meat showed significant difference among the groups $(\mathrm{p}<0.01)$.

Conclusion: Crossbred Hampshire pigs being reared on fermented feed and deep litter housing could produce highlygraded carcass and improvement in meat quality.

Keywords: fermented feed, deep litter housing, crossbred Hampshire pig, carcass characteristics, meat quality.

\section{Introduction}

Conventional pig production systems are generally thought to be associated with poor animal welfare that results in meat quality deterioration [1]. It is generally accepted that environmental enrichment with substrates improves the welfare of growing pigs [2]. Research conducted elsewhere have shown that average daily body weight gain, feed conversion ratio, and survival rate of pigs raised in deeplitter housing system to be equal or superior to those raised in conventional concrete floor pig houses $[3,4]$. There are also benefits for animal welfare by providing a more comfortable lying surface, result in less joint lesions in deep litter system. In this system, pigs get a constant source of manipulable material to exhibit rooting and other natural behaviors [5]. Thus, it is very important

Copyright: The authors. This article is an open access article licensed under the terms of the Creative Commons Attributin License (http:// creative commons.org/licenses/by/2.0) which permits unrestricted use, distribution and reproduction in any medium, provided the work is properly cited. to implement pig production systems that satisfy consumer and citizen demands for lower environmental impact, improved animal welfare, and meat quality.

There is a focus on feeding fermented diet to the pigs as improvement in growth performance through better assimilation of nutrients in the gut and maintenance of gastrointestinal health through improvement in gut microbial ecology have been reported by several researchers [6]. The improved growth performance through feeding of fermented diet to pigs has also been associated with improved carcass characteristics [7]. Besides, it was also reported that tenderness of the pork was increased when pigs were fed with fermented feed [8]. Color parameters of the loin muscle appeared to be improved after feeding fermented feed to the pigs [9].

An experiment was therefore conducted to study the carcass traits and meat quality characteristics of crossbred Hampshire pigs fed with a fermented diet and reared on a deep litter housing system. 


\section{Materials and Methods}

\section{Ethical approval}

The experiment was approved by the Institutional Animal Ethical Committee, College of Veterinary Science, Khanapara, Assam Agricultural University, Guwahati - 781022(Approval No: 770/ac/CPCSEA/ FVSc/AAU/IAEC/11-12/124).

\section{Study area}

The experiment was conducted in the pig farm of the National Agricultural Innovation Project (Component-2), College of Veterinary Science, Assam Agricultural University, Khanapara, Guwahati-22. Forty-eight weaned crossbred (Hampshire X Assam local) 2-month-old healthy piglets were used in this experiment. The animals were divided randomly into 4 homogenous groups with 6 males and 6 females each: $\mathrm{E}_{1}$; reared on a conventional housing and fed with a fermented diet, $E_{2}$; reared on a deep litter housing system and fed with a fermented diet, $\mathrm{E}_{3}$; reared on a deep litter housing system and fed with a conventional diet and $\mathrm{C}$; reared on a conventional housing system and fed with a conventional diet.

\section{Housing of animal and feed fermentation}

In the conventional system, the pigs were kept on a cement concrete floor and in the deep litter housing system, pigs were reared on fermented bedding consisted of sawdust (40\%), paddy husk (20\%), dry soil $(20 \%)$, charcoal $(10 \%)$, dried tree leaves $(10 \%)$, extract of fermented bamboo shoot, black salt, water (less than 30\%), and active culture of Lactobacillus brevis. Conventional feed prepared with various feed ingredients and the parts used are presented in Table-1. For fermentation of feed Lactobacillus plantarum (221) strain was used @ $6 \log _{10}$ cfu/g of feed where feed and water mixed at 2:1 ratio. Proximate composition of conventional and fermented feed are depicted in Table- 2 .

\section{Data collection}

At the end of the experiment (32 weeks) 6 pigs ( 3 males and 3 females) from each experimental group were slaughtered to study the carcass traits and meat quality characteristics. Before, slaughter pigs were overnight starved and water was offered ad libitum. Pre-slaughter weight (kg) of pigs was measured by a digital platform balance. Humane (painless) method of slaughter was followed (the pigs were electrically stunned before bleeding). Hot carcass weight (kg) was also recorded in a track balance prior to chilling and dressing percentage was estimated.

The edible offal viz., heart, liver, and kidney were also weighed. At the same time, the weight $(\mathrm{kg})$ of inedible offal and parts viz., lungs, spleen, alimentary tract, head were recorded immediately after evisceration. Finally, the length $(\mathrm{m})$ and diameter $(\mathrm{mm})$ of small and large intestine were measured by using a measuring tape after removal of the intestinal content, while their weights $(\mathrm{kg})$ were recorded in a digital balance.
Table-1: Parts of ingredients used in the preparation of feed.

\begin{tabular}{lcc}
\hline Ingredients & Grower & Finisher \\
\hline Maize & 50 & 55 \\
Wheat bran & 22 & 22 \\
Groundnut cake & 15 & 10 \\
Soyabean meal & 10 & 10 \\
Mineral mixture & 2.5 & 2.5 \\
Common salt & 0.5 & 0.5 \\
Total & 100.00 & 100.00 \\
Additives: & & \\
Vitamin @ 10g/quintal & & \\
Lysine @ 30g/quintal & & \\
Methionine @ 15g/quintal & & \\
\hline
\end{tabular}

Carcass length was measured in centimeter. The back fat thickness was measured with a metallic tap scale at the level of the first rib, last rib, and last lumbar vertebrae. The average of the 3 measurements was calculated as back fat thickness and expressed in centimeter. The width of loin eye area (circumference of Longissimus dorsi muscle in between the $10^{\text {th }}$ and $11^{\text {th }}$ rib) was measured by a tracing paper by placing it against the cut surface of the eye muscle. The respective area $\left(\mathrm{cm}^{2}\right)$ was measured by using a compensating polar planimeter.

The weight $(\mathrm{kg})$ of wholesale cuts; ham, bacon, loin, boston butt, picnic, and jowl was measured in a digital balance. The chilled meat was separated from the carcass and weight of the meat and bone was estimated to calculate the meat: bone ratio.

Chemical composition viz., moisture, crude protein, ether extract, and total ash content of L. dorsi muscle were analyzed following the procedure described by AOAC [10]. Mineral content (ppm); Zinc, Copper, Iron, Manganese, and Magnesium of L. dorsi muscle was determined by an Atomic Absorption Spectrophotometer (GBC 932 AA) according to the method described by Fick et al [11].

Color parameters of the L. dorsi muscle were measured by a Spectrophotometer (Carry 100 Bio UV-Vis, Varian, Holland) set on the $\mathrm{L}^{*}, \mathrm{a}^{*}$, and $\mathrm{b}^{*}$ system (CIE lab). The color parameters were analyzed using the color coordinates for CIE lab. Tenderness of meat sampleswere determined by using a texture analyzer (Texture analyzer HD plus, Stable micro systems, UK) equipped with a Warner-Bratzler shear blade.

\section{Statistical analysis}

The data were statistically analyzed by using 2 factor (group and sex) complete randomized design with interaction in SAS 9.3 (2013) software available at Bio-statistical laboratory, College of Veterinary Science, Khanapara received from ICAR, New Delhi under NAIP (Component-1). The post hoc test was done by Turkey's honest significant difference test [12].

\section{Results and Discussion}

Carcass characteristics of the different experimental groups are presented in Table-3. The final body weight of pigs revealed a significant $(\mathrm{p}<0.01)$ 
Table-2: Proximate composition of conventional and fermented feed.

\begin{tabular}{lccccc}
\hline \multirow{2}{*}{ Feed } & \multicolumn{5}{c}{ Proximate composition (\%) } \\
\cline { 2 - 6 } & Moisture & Crude protein & Crude fiber & Ether extract & Total ash \\
\hline Grower & & & & & \\
$\quad$ Conventional & $10.78 \pm 0.035$ & $18.15 \pm 0.22$ & $4.24 \pm 0.04$ & $4.08 \pm 0.025$ & $5.31 \pm 0.085$ \\
$\quad$ Fermented & $55.52 \pm 1.14$ & $19.90 \pm 0.22$ & $4.10 \pm 0.05$ & $4.17 \pm 0.09$ & $4.96 \pm 0.06$ \\
Finisher & & & & & \\
$\quad$ Conventional & $10.82 \pm 0.10$ & $15.96 \pm 0.215$ & $5.54 \pm 0.20$ & $4.39 \pm 0.10$ & $5.26 \pm 0.04$ \\
$\quad$ Fermented & $55.98 \pm 0.43$ & $17.49 \pm 0.435$ & $5.17 \pm 0.12$ & $4.49 \pm 0.30$ & $4.63 \pm 0.25$ \\
\hline
\end{tabular}

Table-3: Effect of housing system (deep litter vs. conventional) and feed (fermented vs. conventional) on carcass traits of crossbred Hampshire pigs (values are presented as mean \pm standard error).

\begin{tabular}{|c|c|c|c|c|c|c|c|}
\hline \multirow[t]{2}{*}{ Parameter } & \multicolumn{4}{|c|}{ Groups } & \multicolumn{2}{|c|}{ Sex } & \multirow{2}{*}{$\begin{array}{c}\text { Probability } \\
\text { level }\end{array}$} \\
\hline & $E_{1}$ & $E_{2}$ & $E_{3}$ & $\mathbf{C}$ & M & $\mathbf{F}$ & \\
\hline Initial body weight $(\mathrm{kg})$ & $15.08 \pm 0.48$ & $15.08 \pm 0.51$ & $15.00 \pm 0.50$ & $15.04 \pm 0.51$ & $15.06 \pm 0.32$ & $15.04 \pm 0.37$ & NS \\
\hline Final body weight $(\mathrm{kg})$ & $76.92 \pm 0.97^{b}$ & $84.25 \pm 2.75^{\mathrm{a}}$ & $80.25 \pm 2.08^{\mathrm{ab}}$ & $74.33 \pm 0.74^{c}$ & $80.42 \pm 1.32$ & $77.46 \pm 1.57$ & $* *$ \\
\hline Pre-slaughter weight $(\mathrm{kg})$ & $75.83 \pm 1.66^{a}$ & $87.67 \pm 3.18^{b}$ & $81.33 \pm 3.26^{\mathrm{ab}}$ & $74.00 \pm 1.15^{\mathrm{a}}$ & $80.42 \pm 2.07$ & $79.00 \pm 3.54$ & $* *$ \\
\hline Hot carcass weight $(\mathrm{kg})$ & $54.69 \pm 1.26^{b c}$ & $64.15 \pm 2.21^{\mathrm{a}}$ & $59.47 \pm 2.47^{\mathrm{ab}}$ & $53.27 \pm 0.86^{c}$ & $58.23 \pm 1.52$ & $57.56 \pm 2.00$ & $* *$ \\
\hline Dressing percentage $(\%)$ & $72.11 \pm 0.09^{a}$ & $73.21 \pm 0.45^{\mathrm{b}}$ & $73.11 \pm 0.32^{b}$ & $71.99 \pm 0.29^{a}$ & $72.42 \pm 40$ & $72.81 \pm 0.30$ & $* *$ \\
\hline Head weight $(\mathrm{kg})$ & $6.92 \pm 0.11^{\mathrm{a}}$ & $7.34 \pm 0.10^{\mathrm{a}}$ & $7.19 \pm 0.21^{\mathrm{a}}$ & $6.35 \pm 0.22^{\mathrm{b}}$ & $6.93 \pm 0.14$ & $6.97 \pm 0.18$ & $* *$ \\
\hline Heart $(\mathrm{kg})$ & $0.26 \pm 0.01^{c}$ & $0.32 \pm 0.01^{\mathrm{a}}$ & $0.30 \pm 0.02^{\mathrm{ab}}$ & $0.27 \pm 0.01^{b c}$ & $0.29 \pm 0.01$ & $0.29 \pm 0.01$ & $*$ \\
\hline Kidney (kg) & $0.22 \pm 0.01$ & $0.23 \pm 0.01$ & $0.21 \pm 0.01$ & $0.21 \pm 0.003$ & $0.22 \pm 0.01$ & $0.22 \pm 0.01$ & NS \\
\hline Liver (kg) & $1.39 \pm 0.02^{\mathrm{b}}$ & $1.51 \pm 0.04^{a}$ & $1.42 \pm 0.03^{\mathrm{ab}}$ & $1.37 \pm 0.01^{\mathrm{b}}$ & $1.42 \pm 0.03$ & $1.42 \pm 0.02$ & $*$ \\
\hline Spleen (kg) & $0.21 \pm 0.004$ & $0.23 \pm 0.01$ & $0.23 \pm 0.02$ & $0.20 \pm 0.003$ & $0.21 \pm 0.04$ & $0.22 \pm 0.01$ & NS \\
\hline Lung $(\mathrm{kg})$ & $0.96 \pm 0.04^{a}$ & $1.14 \pm 0.05^{\mathrm{b}}$ & $1.08 \pm 0.06^{\mathrm{ab}}$ & $0.96 \pm 0.03^{a}$ & $1.04 \pm 0.03$ & $1.04 \pm 0.04$ & $*$ \\
\hline Stomach (kg) & $0.85 \pm 0.02$ & $0.90 \pm 0.03$ & $0.90 \pm 0.02$ & $0.85 \pm 0.03$ & $0.87 \pm 0.02$ & $0.88 \pm 0.02$ & NS \\
\hline Carcass length (cm) & $78.33 \pm 0.33$ & $80.17 \pm 1.17$ & $79.67 \pm 1.61$ & $76.17 \pm 1.25$ & $78.33 \pm 0.79$ & $78.83 \pm 1.04$ & NS \\
\hline Backfat thickness $(\mathrm{cm})$ & $2.06 \pm 0.21$ & $2.43 \pm 0.19$ & $2.37 \pm 0.11$ & $2.06 \pm 0.14$ & $2.31 \pm 0.11$ & $2.15 \pm 0.13$ & NS \\
\hline Loin eye area $\left(\mathrm{cm}^{2}\right)$ & $36.00 \pm 1.61$ & $35.58 \pm 0.89$ & $35.67 \pm 0.95$ & $34.83 \pm 1.35$ & $34.62 \pm 0.78$ & $36.42 \pm 0.81$ & NS \\
\hline $\operatorname{Ham}(\mathrm{kg})$ & $12.80 \pm 0.37^{a}$ & $14.85 \pm 0.36^{b}$ & $14.01 \pm 0.30^{\mathrm{b}}$ & $12.64 \pm 0.21^{\mathrm{a}}$ & $13.56 \pm 0.30$ & $13.59 \pm 0.42$ & $* *$ \\
\hline Bacon $(\mathrm{kg})$ & $12.61 \pm 0.26^{a}$ & $15.08 \pm 0.55^{b}$ & $13.96 \pm 0.38^{c}$ & $12.33 \pm 0.18^{\mathrm{a}}$ & $13.80 \pm 0.43$ & $13.18 \pm 0.37$ & $* *$ \\
\hline Loin $(\mathrm{kg})$ & $12.17 \pm 0.52^{\mathrm{a}}$ & $14.60 \pm 0.50^{b}$ & $13.53 \pm 0.83^{\mathrm{ab}}$ & $12.11 \pm 0.18^{\mathrm{a}}$ & $13.09 \pm 0.46$ & $13.12 \pm 0.51$ & $*$ \\
\hline Boston butt (kg) & $8.21 \pm 0.18^{\mathrm{bc}}$ & $9.51 \pm 0.51^{\mathrm{a}}$ & $8.81 \pm 0.32^{\mathrm{ab}}$ & $7.57 \pm 0.33^{c}$ & $8.68 \pm 0.22$ & $8.37 \pm 0.39$ & $* *$ \\
\hline Picnic (kg) & $6.17 \pm 0.08$ & $7.51 \pm 0.70$ & $6.11 \pm 0.73$ & $5.89 \pm 0.24$ & $6.36 \pm 0.36$ & $6.48 \pm 0.44$ & NS \\
\hline Jowl (kg) & $1.75 \pm 0.09$ & $1.84 \pm 0.06$ & $1.79 \pm 0.14$ & $1.75 \pm 0.06$ & $1.78 \pm 0.05$ & $1.78 \pm 0.08$ & NS \\
\hline Meat: Bone ratio & $4.22 \pm 0.19^{b c}$ & $4.54 \pm 0.12^{a}$ & $4.42 \pm 0.13^{\mathrm{ab}}$ & $3.99 \pm 0.09^{c}$ & $4.45 \pm 0.11^{\mathrm{A}}$ & $4.13 \pm 0.11^{\mathrm{B}}$ & $* *$ \\
\hline Length of SI (m) & $16.90 \pm 0.27$ & $17.37 \pm 0.13$ & $17.22 \pm 0.12$ & $16.73 \pm 0.10$ & $17.14 \pm 0.16$ & $16.97 \pm 0.11$ & NS \\
\hline Diameter of SI (mm) & $3.11 \pm 0.03^{a}$ & $3.33 \pm 0.08^{b}$ & $3.27 \pm 0.09^{\mathrm{ab}}$ & $2.80 \pm 0.07 c$ & $3.12 \pm 0.05$ & $3.13 \pm 0.10$ & $* *$ \\
\hline Weight of SI (kg) & $1.11 \pm 0.02^{c}$ & $1.28 \pm 0.03^{a}$ & $1.19 \pm 0.02^{\mathrm{b}}$ & $1.10 \pm 0.02^{c}$ & $1.16 \pm 0.02$ & $1.18 \pm 0.03$ & $* *$ \\
\hline & $6.45 \pm 0.14$ & $6.82 \pm 0.14$ & $6.73 \pm 0.11$ & $6.44 \pm 0.11$ & $6.74 \pm 0.08^{A}$ & $6.48 \pm 0.10^{\mathrm{B}}$ & $*$ \\
\hline $\mathrm{r}$ of LI $(\mathrm{mm})$ & $5.92 \pm 0.09 \mathrm{bc}$ & $6.16 \pm 0.05^{a b}$ & $6.20 \pm 0.13^{a}$ & $5.83 \pm 0.07 c$ & $6.05 \pm 0.05$ & $6.00 \pm 0.10$ & $*$ \\
\hline Weight of LI $(\mathrm{kg})$ & $1.06 \pm 0.05$ & $1.12 \pm 0.07$ & $1.05 \pm 0.07$ & $0.87 \pm 0.05$ & $1.04 \pm 0.05$ & $1.01 \pm 0.05$ & NS \\
\hline
\end{tabular}

abcMeans within a row and group with different superscript significantly differ ABMeans within a row and sex with different superscript significantly differ, $\mathrm{E}_{1}$; reared on a conventional housing and fed with a fermented diet. $\mathrm{E}_{2}$; reared on a deep litter housing system and fed with a fermented diet. $E_{3}$; reared on a deep litter housing system and fed with a conventional diet and $\mathrm{C}$; reared on a conventional housing system and fed with a conventional diet, $* p<0.05, * * p<0.01$, $\mathrm{NS}=\mathrm{p}>0.05$, NS=Non-significant

difference among the groups. Final body weight of pigs in Group $\mathrm{E}_{2}$ was higher than those of Group $\mathrm{E}_{1}$ and $\mathrm{C}$, whereas not varied with Group $\mathrm{E}_{3}$. Furthermore, the final weight of pigs of Group $\mathrm{E}_{1}$ was also higher than those recorded for Group C. Sex did not influence on the final body weight of pigs.

Pre-slaughter weight, hot carcass weight, and dressing percentage of crossbred Hampshire pigs showed a significant $(p<0.01)$ difference among the experimental groups. The pre-slaughter weight of Group $\mathrm{E}_{2}$ was significantly higher than Group $\mathrm{E}_{1}$ and $\mathrm{C}$, but did not differ from Group $\mathrm{E}_{3}$. However, no significant differences were observed among Group $\mathrm{E}_{1}$, $\mathrm{E}_{3}$, and $\mathrm{C}$. In regards to hot carcass weight, Group $\mathrm{E}_{2}$, was higher than Groups $\mathrm{E}_{1}$ and $\mathrm{C}$, but did not differ from Group $\mathrm{E}_{3}$, while the difference observed between Group $\mathrm{E}_{3}$ and $\mathrm{C}$ was found to be significant. Again, the dressing percentage in Group $\mathrm{E}_{2}$ and $\mathrm{E}_{3}$ were higher than those recorded for Group $\mathrm{E}_{1}$ and $\mathrm{C}$. Further, no differences could be observed between Group $\mathrm{E}_{2}$ and $\mathrm{E}_{3}$ and between Group $\mathrm{E}_{1}$ and C. However, sex and interaction of group and sex had no effect. The findings of the present study are in agreement with the report of Paterson et al.[13] who observed that pigs housed in the deep litter were $2 \mathrm{~kg}$ heavier at slaughter than the pigs housed conventionally. In another study, pigs reared on bedded area showed significantly heavier hot carcass weight $(93.2 \mathrm{~kg})$ than those reared on slatted floor $(89.6 \mathrm{~kg})$ [14]. Dressing percentage also reported to be $2 \%$ higher in pigs finished on deep 
bedding as compared to pigs finished on slatted floor housing [15]. However, final body weight, carcass weight, and dressing percentage were not affected when pigs fed with dry pelleted feed, fermented feed,and acidified liquid feed $[9,16]$.

In regards to edible offal, a significant difference could be observed in the weight of heart and liver $(p<0.05)$ among the groups while sex had no effect. Heart weight recorded for Group $\mathrm{E}_{2}$ was higher than those recorded for Group $\mathrm{E}_{1}$ and $\mathrm{C}$ but did not differ from $\mathrm{E}_{3}$. The value recorded for Group $\mathrm{E}_{3}$ also differed from $\mathrm{E}_{1}$ but not with Group C. Furthermore, no difference could be seen between Group $\mathrm{E}_{1}$ and $\mathrm{C}$. The weight of liver recorded for Group $\mathrm{E}_{2}$ was higher than those recorded for Groups $\mathrm{E}_{1}$ and $\mathrm{C}$ but did not differ from Group $\mathrm{E}_{3}$. Analysis also revealed no differences of liver weight among Group $\mathrm{E}_{1}, \mathrm{E}_{3}$, and $\mathrm{C}$. On the other hand; no significant differences were found in relation to the weight of kidney. The weight of expelled blood was also not different among the experimental groups. The results of the present investigation on edible offal of pigs are in close proximity with the findings of Borah [17] who reported that crossbred pigs reared on deep litter and conventional system had weight of liver $(1.56 \pm 0.05$ vs. $1.14 \pm 0.05 \mathrm{~kg})$, weight of heart $(0.27 \pm 0.01$ vs. $0.24 \pm 0.02 \mathrm{~kg})$, and weight of kidney $(0.22 \pm 0.01$ vs. $0.24 \pm 0.02 \mathrm{~kg})$, respectively, and the difference in the weight of liver and heart was statistically significant. In another study, pigs kept in litter bed also had significantly heavier liver and heart weight than those in slatted floor [18].

Among the inedible offal, weight of the head $(p<0.01)$ and lung $(p<0.05)$ differed significantly among the groups. Head weight recorded in Group C was significantly lower than those recorded in Group $\mathrm{E}_{1}, \mathrm{E}_{2}$, and $\mathrm{E}_{3}$. However, no differences could be observed among Group $\mathrm{E}_{1}, \mathrm{E}_{2}$, and $\mathrm{E}_{3}$. Again, the weight of lung in group $\mathrm{E}_{2}$ differed significantly with Group $\mathrm{E}_{1}$ and $\mathrm{C}$, but not with Group $\mathrm{E}_{3}$ while the insignificant difference was observed between Group $\mathrm{E}_{1}$ and $\mathrm{C}$ and between Group $\mathrm{E}_{2}$ and $\mathrm{E}_{3}$. In contrast, no significant difference was noticed in respect of the weight of spleen and stomach among the groups. The result of the present study are in agreement with the findings of Lebret et al.[18] who recorded higher average weight of lung, spleen, gastrointestinal tract, and stomach of pigs slaughtered at $110 \mathrm{~kg}$ reared on sawdust bedding with free access to an outdoor area compared to fully slatted floor. Lung and head weight was not influenced when pigs were fed with different levels of wet brewer's grain (WBG) [19].

In relation to carcass measurements viz., carcass length, backfat thickness, and loin eye area, no significant ( $p>0.05$ ) difference was noticed among the experimental groups. Results obtained in the present study corroborated with the earlier findings [20-23]. Moreover, non-significant difference in carcass measurements of pigs between probiotic treated and untreated group was also observed [7].
Wholesale cuts of crossbred Hampshire pigs revealed significant difference in regards to weight of ham $(p<0.01)$, bacon $(p<0.01)$, loin $(p<0.05)$, and boston butt $(p<0.01)$ among the groups while sex had no influence. Weight of ham in Group $\mathrm{E}_{2}$ and $\mathrm{E}_{3}$ were higher than Group $\mathrm{E}_{1}$ and $\mathrm{C}$, while no difference was observed between Group $\mathrm{E}_{2}, \mathrm{E}_{3}$ and Group $\mathrm{E}_{1}$, C. Weight of bacon in Group $\mathrm{E}_{2}$ was significantly higher than Group $\mathrm{E}_{1}, \mathrm{E}_{3}$, and $\mathrm{C}$. Further, bacon weight recorded for $\mathrm{E}_{3}$ was also higher than those recorded for Group $\mathrm{E}_{1}$ and $\mathrm{C}$ but no difference could be observed between Group $\mathrm{E}_{1}$ and C. Again weight of loin in Group $\mathrm{E}_{2}$ was recorded higher than those for Group $\mathrm{E}_{1}$ and $\mathrm{C}$, however, the differences among Group $\mathrm{E}_{1}, \mathrm{E}_{3}$, and $\mathrm{C}$ were not significant. In the case of weight of Boston butt, Group $\mathrm{E}_{2}$ differed from Group $\mathrm{E}_{1}$ and $\mathrm{C}$ but did not differ with Group $\mathrm{E}_{3}$. Moreover, Group $\mathrm{E}_{3}$ differed from Group C but not with Group $\mathrm{E}_{1}$. Furthermore, no difference was observed between Group $\mathrm{E}_{1}$ and C.Weight of picnic and jowl were notinfluenced by the treatment groups and also by sex. The average meat: Bone ratio of pigs showed a significant difference among the groups and between sexes $(p<0.01)$. However, the interaction of group and sex had no influence on meat: bone ratio. Higher meat: Bone ratio was recorded in Group $\mathrm{E}_{2}$ than those recorded for Group $\mathrm{E}_{1}$ and $\mathrm{C}$ but not differed with Group $\mathrm{E}_{3}$. However, no difference could be observed between Group $\mathrm{E}_{1}$ and $\mathrm{C}$ while Group $\mathrm{E}_{3}$ differed from Group $\mathrm{C}$. The male pigs had higher meat: bone ratio than the female pigs. The results of the present study correspond to the findings of Zhou et al. [21] and Pugliese et al.[24], who reported higher percentage of loin, ham, shoulder, jowl, and lean cuts in outdoor pigs than those reared indoors. The outdoor pigs also had lower percentage of bone and lean: bone ratio (12.33 vs. 12.49 and 7.08 vs. 7.14 , respectively) when compared to indoor pigs [25]. Pigs kept in the deep litter system had higher meat: Bone ratio than those in a conventional system $(p<0.01)$ [17].

Morphometry of intestine revealed a significant difference in respect of diameter $(p<0.01)$ and weight $(p<0.01)$ of small intestine among the groups but the length of the small intestine was not affected. Diameter of small intestine recorded in Group $E_{2}$ was found to be higher than group $\mathrm{E}_{1}$ and $\mathrm{C}$, while not varied with $E_{3}$. The value recorded for $E_{3}$ and $C$ were also varied with Group C; however, no difference was noticed between Group $\mathrm{E}_{1}$ and $\mathrm{E}_{3}$. Weight of small intestine was found to be higher in Group $\mathrm{E}_{2}$ than Group $\mathrm{E}_{1}, \mathrm{E}_{3}$, and $\mathrm{C}$. Further, weight of SI in Group $\mathrm{E}_{3}$ also higher than Group $E_{1}$ and $C$, but no difference was observed between Group $\mathrm{E}_{1}$ and $\mathrm{C}$. On the other hand, diameter of large intestine showed significant difference among the groups $(p<0.05)$. The diameter of LI was found to be higher in Group $\mathrm{E}_{3}$ than $\mathrm{E}_{1}$ and $\mathrm{C}$ but not differed with $E_{2}$. The values recorded for $E_{2}$ were also varied with those recorded for Group $\mathrm{C}$, however, no difference could be observed between Group $\mathrm{E}_{1}$ and $\mathrm{C}$. Length 
of large intestine in male pigs was found to besignificantly higher than those recorded for the females $(p<0.05)$. Weight of large intestine neither influenced by the experimental groups nor by sexes. When pigs fed high-fiber diets, a significant extension of the Gastrointestinaltract (GI) is observed as a response to the increased volume of the digesta and the increased secretion of digestive fluid [26]. Anincreasing trend of weights of the pig intestine after increasingthe level of WBGdietary supplementation was observed, although the differences were not significant [7].

The chemical composition of $L$. dorsi muscle revealed significant differences in regards to moisture and total ash content among the groups $(\mathrm{p}<0.05)$ (Table-4). Moisture percent of pork in Group $\mathrm{E}_{1}$ was estimated to be higher than those of Group $\mathrm{E}_{3}$ and $\mathrm{C}$, but not varied with Group $\mathrm{E}_{2}$. Further, no difference was observed among Group $\mathrm{E}_{2}, \mathrm{E}_{3}$, and $\mathrm{C}$. Total ash content was found to be higher in Group $\mathrm{E}_{3}$ and $\mathrm{C}$, than those recorded for $E_{1}$ and $E_{2}$. However, no difference was observed between Group $\mathrm{E}_{1}$ and $\mathrm{E}_{2}$; and $\mathrm{E}_{3}$ and $\mathrm{C}$. Moreover, no significant differences were observed in respect to crude protein and ether extract content. Pork produced in the deep litter had higher crude protein content than that of a conventional system as it was found in a previous study [26]. Pigs reared outdoor also hadhigher crude protein content in meat compared to that of indoor reared pigs [27,28]. In the present study, crude protein level appeared to be slightly higher in pigs reared on deep litter system than that of theconventional system although the difference was not significant. Furthermore, pigs which fed fermented feed had lower ash content in the $L$. dorsi muscle than those fed conventional feed. This finding is not in agreement with the results of a previous study, where the ash content of the muscle was found to be increased as the level of incorporation of fermented feed increased [29].

The mineral concentration viz., $\mathrm{Zn}, \mathrm{Cu}, \mathrm{Fe}, \mathrm{Mn}$, and $\mathrm{Mg}$ concentration of $L$. dorsi muscle of pigs did not vary among the groups, between sex and interaction of group and sex (Table-4). However, an earlier report of Gentry et al. [22] showed that pigs reared outdoor had higher plasma iron content than pigs reared indoors.

Values of color parameters in the $L$. dorsi muscle were significantly different among groups $(p<0.05)$. The $\mathrm{L}^{*}$ value was found to be higher in Group $\mathrm{E}_{1}$ than those of Group $\mathrm{E}_{3}$ and $\mathrm{C}$ but did not differ from Group $\mathrm{E}_{2}$. The difference between Group $\mathrm{E}_{3}$ and $\mathrm{C}$ also not varied. The value of parameter $\mathrm{a}^{*}$ in Group $\mathrm{E}_{2}$ was appeared to be higher than the other experimental groups. However, the differences among Group $\mathrm{E}_{1}, \mathrm{E}_{3}$, and $\mathrm{C}$ were not significant. For the parameter $\mathrm{b}^{*}$ the differences among the groups were not significant. The results of the present study are in agreement with the findings of Dimatteo et al [30] and Trezona et al [31] who reported that color parameters for $L^{*}, a^{*}, b^{*}$ of the quadriceps femoris and L. dorsi muscle were significantly $(\mathrm{p}<0.05)$ higher in meat of pigs reared in straw bedded than concrete floor. On the other hand, pigs which fed fermented food waste feed had higher $\mathrm{L}^{*}$ and lower $\mathrm{a}^{*}$ value in loin muscle that those fed control ration [9].

In regards to the textural properties of meat, shear force value of $L$. dorsi muscle showed a significant difference $(p<0.01)$ among the experimental groups. Pork produced in Group $\mathrm{C}$ was found to be less tender than the other experimental groups. However, no significant differences could be observed among Group $\mathrm{E}_{1}$,

Table-4: Effect of housing system (deep litter vs. conventional) and feed (fermented vs. conventional) on chemical composition, mineral profile, color parameters, and shear force value of $L$. dorsi muscle of crossbred Hampshire pigs of experimental groups (values are presented as meantstandard error).

\begin{tabular}{|c|c|c|c|c|c|c|c|}
\hline \multirow[t]{2}{*}{ Parameter } & \multicolumn{4}{|c|}{ Groups } & \multicolumn{2}{|c|}{ Sex } & \multirow{2}{*}{$\begin{array}{c}\text { Probability } \\
\text { level }\end{array}$} \\
\hline & $E_{1}$ & $E_{2}$ & $\mathbf{E}_{3}$ & C & $\mathbf{M}$ & $\mathbf{F}$ & \\
\hline Moisture (\%) & $74.70 \pm 0.16^{a}$ & $74.32 \pm 0.18^{\mathrm{ab}}$ & $74.08 \pm 0.09^{b}$ & $74.07 \pm 0.09^{b}$ & $74.41 \pm 0.11$ & $74.18 \pm 0.12$ & $*$ \\
\hline $\begin{array}{l}\text { Crude protein } \\
(\%)\end{array}$ & $21.26 \pm 0.19$ & $21.63 \pm 0.28$ & $21.76 \pm 0.27$ & $21.29 \pm 0.27$ & $21.42 \pm 0.21$ & $21.55 \pm 0.15$ & NS \\
\hline $\begin{array}{l}\text { Ether extract } \\
(\%)\end{array}$ & $2.54 \pm 0.07$ & $2.45 \pm 0.05$ & $2.56 \pm 0.06$ & $2.42 \pm 0.05$ & $2.55 \pm 0.05$ & $2.44 \pm 0.02$ & NS \\
\hline Total ash (\%) & $1.00 \pm 0.04^{a}$ & $1.01 \pm 0.39^{a}$ & $1.12 \pm 0.04^{b}$ & $1.16 \pm 0.02^{b}$ & $1.10 \pm 0.03$ & $1.05 \pm 0.03$ & $*$ \\
\hline $\mathrm{Zn}(\mathrm{ppm})$ & $2.38 \pm 0.46$ & $2.19 \pm 0.44$ & $2.59 \pm 0.29$ & $2.62 \pm 0.18$ & $2.04 \pm 0.24$ & $2.85 \pm 0.13$ & NS \\
\hline $\mathrm{Cu}(\mathrm{ppm})$ & $1.23 \pm 0.65$ & $1.25 \pm 0.45$ & $0.49 \pm 0.21$ & $0.80 \pm 0.29$ & $0.70 \pm 0.20$ & $1.19 \pm 0.36$ & NS \\
\hline $\mathrm{Fe}(\mathrm{ppm})$ & $2.15 \pm 0.26$ & $2.03 \pm 0.27$ & $2.28 \pm 0.85$ & $2.84 \pm 1.03$ & $1.78 \pm 0.23$ & $2.87 \pm 0.55$ & NS \\
\hline$M n(p p m)$ & $0.17 \pm 0.09$ & $0.29 \pm 0.11$ & $0.34 \pm 0.10$ & $0.50 \pm 0.38$ & $0.16 \pm 0.06$ & $0.49 \pm 0.18$ & NS \\
\hline $\mathrm{Mg}(\mathrm{ppm})$ & $3.31 \pm 0.32$ & $3.07 \pm 0.11$ & $3.76 \pm 0.62$ & $2.95 \pm 0.34$ & $3.10 \pm 0.16$ & $3.45 \pm 0.35$ & NS \\
\hline $\mathrm{L}^{*}$ & $2.13 \pm 0.02^{\mathrm{a}}$ & $2.10 \pm 0.01^{\mathrm{ab}}$ & $2.08 \pm 0.01^{\mathrm{b}}$ & $2.09 \pm 0.01^{b}$ & $2.10 \pm 0.01$ & $2.11 \pm 0.01$ & $*$ \\
\hline a* & $0.06 \pm 0.01^{a}$ & $0.09 \pm 0.01^{b}$ & $0.04 \pm 0.005^{a}$ & $0.05 \pm 0.01^{a}$ & $0.06 \pm 0.01$ & $0.06 \pm 0.01$ & $*$ \\
\hline$b^{*}$ & $0.79 \pm 0.01$ & $0.75 \pm 0.01$ & $0.77 \pm 0.01$ & $0.76 \pm 0.01$ & $0.77 \pm 0.01$ & $0.77 \pm 0.01$ & NS \\
\hline $\begin{array}{l}\text { Shear force } \\
\text { value }(\mathrm{kg})\end{array}$ & $0.0079 \pm 0.002^{\mathrm{a}}$ & $0.0077 \pm 0.002^{\mathrm{a}}$ & $0.011 \pm 0.002^{\mathrm{a}}$ & $0.0164 \pm 0.001^{\mathrm{b}}$ & $0.0113 \pm 0.002$ & $0.0103 \pm 0.001$ & $* *$ \\
\hline
\end{tabular}

abmeans within a row and group with different superscript significantly differ, abmeans within a row and sex with different superscript significantly differ, $E_{1}$; reared on a conventional housing and fed with a fermented diet, $E_{2}$; reared on a deep litter housing system and fed with a fermented diet, $E_{3}$; reared on a deep litter housing system and fed with a conventional diet and, $\mathrm{C}$; reared on a conventional housing system and fed with a conventional diet, $* p<0.05, * * p<0.01$, $\mathrm{NS}=\mathrm{p}>0.05$, NS=Non-significant 
$\mathrm{E}_{2}$, and $\mathrm{E}_{3}$. The present findings corroborated with reports made by Beattie et al. [28] who found tender pork produced by deep litter pigs than those from the slatted floor. In another investigation, it was observed that shear force value decreased by $11.76 \%$ in pork from pigs reared in deep fermented litter than conventionally kept pigs [20]. A possible explanation for this difference is that enriched pigs had higher levels of intramuscular fat, which are associated with improved tenderness and water holding capacity in pork [32]. On the other hand, pigs fed with fermented feed produced tender pork than those fed control feed [8] which is in agreement with the results of the present study.

\section{Conclusion}

From the present study, it may be concluded that crossbred Hampshire pigs Group $\mathrm{E}_{2}$ (reared on a deep litter housing system and fed with a fermented diet) showed increased slaughter weight and hot carcass weight than the other experimental groups. Dressing percentage calculated for $\mathrm{E}_{2}$ Group was higher by $1.1 \%$ over $\mathrm{E}_{1}$ (reared on a conventional housing and fed with a fermented diet), $0.1 \%$ over Group $\mathrm{E}_{3}$ (reared on a deep litter housing system and fed with a conventional diet), and $1.22 \%$ over Group C (reared on a conventional housing system and fed with a conventional diet). The carcass measurements were affected neither by rearing system nor by feeding fermented feed. Crossbred pigs of $\mathrm{E}_{2}$ Group showed improved wholesale cuts than the other experimental groups. Finally, crossbred pigs reared in Group $\mathrm{E}_{1}$ produced brighter meat while those of $\mathrm{E}_{2}$ Group produced more red meat. Meat of $\mathrm{E}_{2}$ Group was found to be softer than that of other experimental groups. Therefore, deep litter housing and feeding of fermented feed may be suggested for improvement in carcass characteristics and meat quality of crossbred Hampshire pigs.

\section{Author's Contributions}

This experiment was a Ph.D. Research study of the first author MR. JRB acted as major advisor and contributed immensely right from the start to end of the experiment. AKS contributed in statistical analysis part. RR and $\mathrm{AB}$ contributed valuable suggestions during the experiment. All authors read and approved the final manuscript.

\section{Acknowledgments}

The authors are thankful to Director of Post Graduate Studies, Assam Agricultural University, Khanapara, Guwahati-22 for kind approval and providing necessary funds and facilities to conduct the experiment.

\section{Competing Interests} interests.

The authors declare that there have no competing

\section{References}

1. Ngapo, T.M., Dransfield, E., Martin,, Magnusson, M., Bredahl, L. and Nute, G.R. (2003) Consumer perceptions:
Pork and pig production. Insights from France, England, Sweden, and Denmark. Meat Sci., 66:125-134.

2. Arey, D.S. (1993) The effect of bedding on the behaviour and welfare of pigs. Anim. Welfare, 2: 235-246.

3. Correa, E.K., Bianchi, I., Ulguim, R.R., Correa, M.N., GilTurnes, C. and Lucia Jr., T. (2009) Effects of different litter depths on environmental parameters and growth performance of growing finishing pigs. Cien. Rural, Santa Maria, 39(3): 838-843.

4. Sheen, S.Y., Su, C.C., Lee, M.S., Chang, H.L. and Hong, C.M. (2005) Study on the management model of litter bedded pig houses. Livest. Res., 34(2): 69-78.

5. Morrison, R.S., Johnston, L.J. and Hilbrands, A.M. (2007) The behaviour, welfare, growth performance and meat quality of pigs housed in a deep-litter, large group housing system compared to a conventional confinement system. Appl. Anim. Behav. Sci., 103: 12-24.

6. Cho, J.H., Zhao, P.Y. and Kim, I.H. (2011) Probiotics as a dietary additives for pigs. J. Anim. Vet. Adv., 10(16): 2127-2134.

7. Ganeshkumar, S., Gnanaraj, P.T., Sivakumar, T., Karthickeyan, S.M.K. and Murugan, M. (2009) Effect of probiotic supplementation on the carcass traits and sensory qualities of swill fed pork. Tamilnadu J. Vet. Anim. Sci., 5(4): 157-160.

8. Suo, C., Yin, Y., Wang, X., Lou, X., Song, D., Wang, X. and $\mathrm{Gu}, \mathrm{Q}$. (2012) Effects of Lactobacillus plantarum ZJ316 on pig growth and pork quality. BMC Vet. Res., 8(89): 1-12.

9. Keun-Kyu,P., Hong-Yang, P.,Young-Chul,J., Eui-Soo,L., Si-Yong,Y., Byoung-Soon,I. and Cheon-Jei,K. (2005) Effects of fermented food waste feeds on pork carcass and meat quality properties. Korean J. Food Sci. Technol., 37(1): $38-43$

10. AOAC. (2005) Official Methods of Analysis. $8^{\text {th }}$ ed. Association of Analytical Chemists, Gaithersburg MD.

11. Fick, K.R., Mc Dowell, L.R., Miles, P.H., Wilkinson, N.S., Funk, J.D. and Conrad, J.H. (1979) Methods of mineral analysis for plant and animal tissue. $2^{\text {nd }} e d$. University of Florida, Gainesville.

12. SAS Institute Inc (2013). Administering SAS Enterprise Guide 9.3, Cary, NC: SAS Institute Inc.

13. Paterson, J.E., Trezona, M., Mullan, B.P., Pluske, J.R., Pethick, D.W. and D'Souza, D.N. (2005), Effect of conventional and deep litter housing on pig growth performance and carcass characteristics. Manipulating pig production X. Proceeding of Tenth Biennial Conference of the Australian Pig Science Association (APSA) held in Christ Church, New Zealand.p276.

14. Lebret,B.,Prunier,A., Bonhomme, N., Foury,A., Mormede,P. and Dourmad, J.Y. (2011) Physiological traits and meat quality of pigs as affected by genotype and housing system. Meat Sci., 88(1): 14-22.

15. Gentry, J.C., McGlone, J.J., Blanton Jr., J.R., Miller, M.F. (2002) Alternative housing systems for pigs: Influences on growth, composition, and pork quality. J. Anim. Sci., 80:1781-1790.

16. Lawlor, P.G., Lynch, P.B., Gardiner, G.E., Caffrey, P.J. and O'Doherty, J.V. (2002) Effect of liquid feeding weaned pigs on growth performance to harvest. J. Anim. Sci., 80: $1725-1735$.

17. Borah, P. (2013) Wean-Finish performance and carcass characteristics of crossbred Hampshire pigs reared in conventional and deep litter housing. M.V.Sc. Thesis, Assam Agricultural University, Jorhat.

18. Lebret, B., Meunier-Salaun, M.C., Foury, A., Mormede, P., Dransfield, E. and Dourmad, J.Y. (2006) Influence of rearing conditions on performance, behavioral, and physiological responses of pigs to preslaughter handling, carcass traits, and meat quality. J. Anim Sci., 84: 2436-2447.

19. Aguilera-Soto, J.I., Ramirez-Lozano, R.G. and MendezLlorente, F. (2008) Effect of fermentable liquid diets based on wet brewers grains on performance and carcass 
characteristics by growing pigs. Conference on International Research on Food Security, Natural Resource Management and Rural Development, University of Hohenheim.

20. Liang, T.M. (2011) Effects of raising pigs on fermentation bed on environment in swine house, growth performance and meat quality. Master's Degree Thesis, Xinjiang Agricultural University.

21. Zhou, Y.G., Wen, A.Y., Ning, K.J.N., Xu, B.N., Xie, J.L, Tang, H. and Liu, S.Q. (2011),Effects of biological fermentation bed on growth performance and pork quality of growing-finishing pigs. J. Anhui Sci. Technol., 1:004.

22. Gentry, J.G., McGlone, J.J., Miller, M.F. and Blanton, Jr., J.R. (2004), Environmental effects on pig performance, meat quality, and muscle characteristics. J. Anim. Sci. 82: 209-217.

23. Kim, D.H., Seong, P.N., Cho, S.H., Kim, J.H., Lee, J.M., Jo, C.and Lim, D.G. (2009) Fatty acid composition and meat quality traits of organically reared Korean native black pigs. Livest. Sci., 120: 96-102.

24. Pugliese, C., Madonia, G., Chiofalo, V., Margiotta, S., Acciaioli, A. and Gandini, G. (2003) Comparison of the performances of nerosicilianopigs reared indoors and outdoors.1. Growth and carcass composition. Meat Sci., 65: 825-831.

25. Sirtori, F., Crovetti, A., Zilio, D.M., Pugliese, C., Acciaioli, A., Campodoni, G., Bozzi, R. and Franci, O. (2011) Effect of sire breed and rearing system on growth, carcass composition and meat traits of cintasenesecrossbred pigs. Ital. J. Anim. Sci., 10: 47.
26. Wenk, C. (2001) The role of dietary fibre in the digestive physiology of the pig. Anim. Feed Sci. Technol., 90: 21-23.

27. Enfalt, C.A., Lundstrom, K., Hansson, I., Lundeheim, N. and Nystrom, E.P. (1997) Effects of outdoor rearing and sire breed (Duroc or Yorkshire) on carcass composition and sensory and technological meat quality. Meat Sci., 45(1): 1-15.

28. Beattie, V.E., O'Connell, N.E. and Moss, B.W. (2000) Influence of environmental enrichment on the behaviour, performance and meat quality of domestic pigs. Livest. Prod. Sci., 65: 71-79.

29. Aro, S.O. and Akinjokun, O.M. (2012) Meat and carcass characteristics of growing pigs fed microbially enhanced cassava peel diets. Arch. Zootec.,61(235): 407-414.

30. Dimatteo, S., Ragni, M., Tarricone, S., Melodia, L., Zarilli, A. and Marsico, G. (2006) Effect of the rearing system on meat quality of cross-bred F2 (Wild boar $\times$ pig). $52^{\text {th }}$ International Congress of Meat Science and Technology, August 13-18, Dublin, Ireland-UNICEB, 2005 Eurocarni, N. 2/2005.

31. Trezona, M., Mullan, B.P., Pluske. J.R., Pethick, D.W. and D'Souza, D.N. (2006) Straw intake affects carcass quality and pork quality. In: $52^{\text {nd }}$ International Congress of Meat Science and Technology.p109-110.

32. Candek-Potokar, M., Zlender, B. and Bonneau, M. (1998) Effects of breed and slaughter weight on longissimus muscle biochemical traits and sensory quality in pigs. Ann. Zootech., 47: 3-16. 